\title{
Analisis Kandungan Fitokimia dan Aktivitas Antioksidan Mikroalga Chlorella sp. Berdasarkan Variasi Waktu Pencahayaan
}

\author{
Hartini $\mathrm{H}^{*}$, Karolina Rosmiati, Agnes Farianti Rezeki Sihombing \\ Akademi Kesehatan John Paul II Pekanbaaru, Riau, Indonesia
}

\section{Article Information :}

Submission: Sept 18, 2021; Revised:Nov 18, 2021; Accepted:Dec 30, 2021; Available online: Dec 31,2021

*Corresponding author : hartini.h@akjp2.ac.id

\begin{abstract}
ABSTRAK
Mikroalga mengandung metabolit sekunder yang potensial untuk dikembangkan. Metabolit sekunder digunakan untuk pertahanan kimia terhadap predator di lingkungan air. Salah satu jenis mikroalga yang dapat dikembangkan metabolit sekundernya adalah Chlorella sp. Kondisi lingkungan saat kultivasi Chlorella sp. mempengaruhi jumlah sel, kandungan metabolit sekunder dan kestabilan senyawa antioksidan mikroalga. Faktor lingkungan yang menjadi fokus penelitian adalah faktor cahaya. Penelitian ini bertujuan untuk menganalisis kandungan fitokimia dan antioksidan biomassa mikroalga Chlorella sp. dengan variasi waktu pencahayaan. Variasi pemberian cahaya pada proses kultivasi menggunakan periode terang : gelap yang terbagi menjadi 2 kelompok yaitu 12:12 (terang:gelap) jam dan 18:6 (terang:gelap) jam. Metode yang digunakan untuk analisis kandungan fitokimia menggunakan metode Harborne dan analisis aktivitas antioksidan menggunakan metode DPPH (1,1-diphenyl-2-picrylhydrazyl). Hasil penelitian menunjukkan bahwa ekstrak mikroalga Chlorella sp. dengan variasi waktu pencahayaan (terang:gelap) 12:12 jam mengandung alkaloid, flavonoid, saponin, steroid, kuinon dan terpenoid. Sedangkan, ekstrak mikroalga Chlorella sp. dengan variasi waktu pencahayaan (terang:gelap) 18:6 jam mengandung alkaloid, flavonoid, saponin dan terpenoid. Hasil aktivitas antioksidan ekstrak mikroalga Chlorella sp. dengan variasi waktu pencahayaan (terang:gelap) 12:12 jam $I_{50}$ sebesar 40,421 dan ekstrak Chlorella sp. dengan variasi waktu pencahayaan (terang:gelap) 18:6 jam memiliki $I_{50}$ sebesar 8,992. Berdasarkan penelitian diperoleh bahwa ekstrak mikroalga yang diberi waktu pencahayaan tinggi menghasilkan aktivitas antioksidan yang lebih kuat dibandingkan pencahayaan rendah.
\end{abstract}

Kata kunci : fitokimia, antioksidan, mikroalga, Chlorella sp.

\begin{abstract}
Microalgae contain potential secondary metabolites to be developed. Secondary metabolites are used for chemical defense against predators in the aquatic environment. One type of microalgae that can be developed secondary metabolites is Chlorella sp. Environmental conditions during the cultivation of Chlorella sp. affect the number of cells, the content of secondary metabolites and the stability of microalgae antioxidant compounds. The environmental factor that is the focus of the research is the light factor. This study aimed to analyze the phytochemical and antioxidant content of microalgae Chlorella sp. with
\end{abstract}


variations in exposure time. The variation of light in the cultivation process uses a period of light: dark which is divided into 2 groups, namely $12: 12$ (light:dark) hours and 18:6 (light:dark) hours. The method used for the analysis of phytochemical content using the Harborne method and the analysis of antioxidant activity using the DPPH (1,1-diphenyl-2picrylhydrazyl) method. The results showed that the extract of the microalgae Chlorella sp. with variations in lighting time (light:dark) 12:12 hours containing alkaloids, flavonoids, saponins, steroids, quinones and terpenoids. Meanwhile, the extract of microalgae Chlorella sp. with variations in lighting time (light:dark) 18:6 hours containing alkaloids, flavonoids, saponins and terpenoids. The results of the antioxidant activity of the microalgae extract Chlorella sp. with variations in lighting time (light:dark) 12:12 hours IC50 of 40,421 and extracts of Chlorella sp. with variations in lighting time (light:dark) 18:6 hours has an IC50 of 8,992. Based on the research, it was found that microalgae extract given high exposure time produced stronger antioxidant activity than low light.

Keywords: phytochemistry, antioxidant, microalgae, Chlorella sp.

\section{PENDAHULUAN}

Penelitian tentang aktivitas antioksidan dan senyawa bioaktif atau metabolit sekunder yang aman bagi kesehatan pada saat ini mengarah pada eksplorasi sumber daya laut (Karseno et al., 2013). Mikroorganisme laut yang potensial untuk dikembangkan salah satunya Chlorella sp. Mikroalga Chlorella sp. mengandung karbohidrat, lipid, protein, dan senyawa bioaktif atau metabolit sekunder. Karbohidrat Chlorella sp. telah dimanfaatkan sebagai bahan bakar berupa bioetanol dan lipidnya dimanfaatkan sebagai bahan baku penghasil biodiesel (Demirbas \& Demirbas, 2010). Biopigmen yang terkandung dalam mikroalga juga dimanfaatkan sebagai sel surya (Nurachman et al., 2015) dan antibakteri (Acurio et al., 2018).

Selain itu Chlorella sp. juga mengandung antioksidan yang dapat dimanfaatkan untuk menunda, memperlambat dan mencegah proses oksidasi (Novianti et al., 2019). Antioksidan alami tersebut sangat bermanfaat bagi tubuh yang mampu melindungi tubuh dari penyakit degeneratif, kanker, dan antiaging. Keuntungan lain dari Chlorella sp. yaitu dapat dikultivasi pada bioreaktor dengan kondisi terkendali dan kemampuan menghasilkan senyawa metabolit sekunder sebagai respon terhadap kondisi lingkungan yang ekstrim seperti cahaya dan nutrisi.

Berdasarkan hasil penelitian penelitian sebelumnya diketahui sumber cahaya yang berasal dari lampu Light Emiting Diode (LED) merupakan sumber cahaya artifisial yang ideal untuk kultivasi Chlorella sp. Selain itu penggunaan LED pada kultivasi dapat menginduksi stres cahaya sehingga mampu menghasilkan metabolisme sekunder yang berpotensi sebagai antioksidan (Novianti et al., 2019).

Penelitian Metsoviti et al., (2020) menyatakan bahwa tingginya intensitas cahaya semakin mempercepat pertumbuhan sel dan meningkatkan jumlah lipid mikroalga. Oleh karena itu, peneliti ingin melakukan uji fitokimia dan aktifitas antioksidan dari Chlorella $\mathrm{sp}$ yang dikultivasi dengan variasi waktu pencahayaan. Penelitian ini bertujuan untuk menganalisis kandungan fitokimia dan antioksidan biomassa mikroalga Chlorella sp. dengan variasi waktu pencahayaan.

\section{METODE PENELITIAN}

Penelitian ini dilakukan di Laboratorium Penelitian AKJP II Pekanbaru. Tahapan penelitian terdiri dari kultivasi mikroalga Chlorella sp. pada medium Walne dengan variasi cahaya (terang:gelap) yaitu kelompok 12:12 (terang:gelap) jam dan 18:6 (terang:gelap) jam serta pemanenan mikroalga untuk memperoleh biomassa. Biomassa diekstraksi dengan pelarut etanol untuk memperoleh ekstrak kasar mikroalga Chlorella sp. Analisis kandungan fitokimia yang terdapat di dalam ekstrak mikroalga Chlorella sp. dilakukan dengan metode Harborne (1998) yang diadopsi dari Harborne. Aktivitas andtioksidan diuji dengan DPPH (1,1-diphenyl-2picrylhydrazyl) mengacu pada Novianti et al., (2019). Alat yang digunakan pada penelitian ini yaitu Alat yang digunakan 
adalah haemocytometer, pipet mikro, mikroskop, spektrofotometer Genesys 105, sentrifuga, neraca analitik, autoklaf, oven, aerator, selang plastik, sumbat karet, aqua botol, timer, lampu, botol semprot, kertas saring dan peralatan gelas lainnya. Bahan yang digunakan yaitu, kultur mikroalga Chlorella sp., akuades, etanol $70 \%$, reagen Wagner, $\mathrm{NaOH} 10 \%, \mathrm{HCl}$ pekat, $\mathrm{FeCl}_{3} 1 \%$, $\mathrm{H}_{2} \mathrm{SO}_{4}$ pekat, DPPH, vitamin C.

\section{Kultivasi Chlorella sp.}

Mikroalga Chlorella sp. dimasukkan sebanyak $90 \mathrm{~mL}$ ke dalam $810 \mathrm{~mL}$ air laut steril didalam botol kaca (beaker glass). Kemudian ditambahkan medium Walne 1 $\mathrm{mL}$ dan diberi aerasi udara selama 24 jam. Penelitian ini menggunakan 2 perlakuan variasi cahaya dengan 3 kali pengulangan. Selanjutnya mikroalga diinkubasi selama 10 hari dengan pemberian cahaya menggunakan variasi periode terang:gelap yaitu 12:12 (terang:gelap) jam dan 18:6 (terang:gelap) jam. Setelah itu dipanen dengan metode sentrifugasi pada kecepatan 7000 rpm selama 15 menit untuk memperoleh biomassa basah. Selanjutnya biomassa basah dikeringanginkan selama 2 hari sehingga diperoleh biomassa kering mikroalga Chlorella sp.

\section{Ekstraksi mikroalga Chlorella sp.}

Biomassa kering Chlorella sp. sebanyak $100 \mathrm{~g}$ diekstraksi dengan cara maserasi (perendaman) dalam etanol $70 \%$ sebanyak $1 \mathrm{~L}$ pada suhu kamar dan dimasukkan dalam wadah tertutup. Proses maserasi dilakukan selama 72 jam dan dilakukan penyaringan dengan kertas saring untuk memperoleh maserat. Maserat yang diperoleh diuapkan hingga diperoleh ekstrak kental (ekstrak kasar).

\section{Analisis Fitokimia Ektrak kasar Chlorella sp.}

Analisis kandungan fitokimia yang terdapat di dalam ekstrak mikroalga Chlorella sp. dilakukan dengan metode Harborne (1998).

\section{Uji Aktivitas Antioksidan}

Ekstrak kasar Chlorella sp. dibuat dalam konsentrasi $50 \mu \mathrm{g} / \mathrm{mL}$. $75 \mu \mathrm{g} / \mathrm{mL}$, $100 \mu \mathrm{g} / \mathrm{mL}, 125 \mu \mathrm{g} / \mathrm{mL}$ dan $150 \mu \mathrm{g} / \mathrm{mL}$ ditambahkan kedalam $2 \mathrm{~mL}$ DPPH 0,1 mM.
Campuran selanjutnya dikocok dan diinkubasi pada suhu kamar selama 30 menit ditempat gelap. Larutan ini selanjutnya diukur absorbansinya pada Amaks $516 \mathrm{~nm}$ (skrining panjang gelombang dari 400-600 nm). Perlakuan yang sama juga dilakukan untuk larutan blanko (larutan DPPH yang tidak mengandung bahan uji) dan kontrol positif vitamin $C$ dengan konsentrasi $2 \mu \mathrm{g} / \mathrm{mL}, 3$ $\mu \mathrm{g} / \mathrm{mL}$, $4 \mu \mathrm{g} / \mathrm{mL}, 5 \mu \mathrm{g} / \mathrm{mL}$, dan $6 \mu \mathrm{g} / \mathrm{mL}$. $\lambda$ maks yang digunakan untuk vitamin $C$ adalah $515 \mathrm{~nm}$. Larutan blanko terdiri dari 2 $\mathrm{mL}$ DPPH 0,1 mM dan $1 \mathrm{~mL}$ etanol p.a. Data hasil pengukuran absorbansi dianalisa persentase aktivitas antioksidannya menggunakan persamaan:

$$
\% \text { Inhibisi }=\frac{\left(A_{\mathrm{DPPH}}-A_{\text {Sampel }}\right)}{A_{\mathrm{DPPH}}} \times 100 \%
$$

Keterangan:

$A_{\text {DPPH }}:$ Absorbansi larutan DPPH (blanko) $A_{\text {Sampel }}$ : Absorbansi sampel.

Nilai konsentrasi penghambatan aktivitas radikal bebas sebanyak 50\% Inhibitory Concentration $\left(\mathrm{IC}_{50}\right)$ dihitung dengan menggunakan persamaan regresi yang diperoleh dari perpotongan garis antara daya hambatan dan sumbu konsentrasi, kemudian dimasukan ke dalam persamaan $\mathrm{y}=\mathrm{a}+\mathrm{bx}$, dengan $\mathrm{y}=50$ dan nilai $\mathrm{x}$ menunjukan $\mathrm{IC}_{50}$. Penggolongan aktivitas antioksidan ini menurut Molyneux (2004) berdasarkan pada nilai $I_{50}$ yang dimiliki oleh suatu bahan, yaitu sangat kuat $\left(\mathrm{IC}_{50}<50 \mathrm{ppm}\right)$, kuat $(50 \mathrm{ppm}<$ $\left.\mathrm{IC}_{50}<100 \mathrm{ppm}\right)$, sedang $(100 \mathrm{ppm}<$ $\mathrm{IC}_{50}<150$ ppm), lemah (150 ppm< $\left.\mathrm{IC}_{50}<200 \mathrm{ppm}\right)$ dan sangat lemah $\left(\mathrm{IC}_{50}>200 \mathrm{ppm}\right)$.

\section{HASIL DAN PEMBAHASAN}

\section{Kultur Chlorella sp.}

Pada tahap pertama yaitu kultivasi Chlorella sp., dalam hal ini mikroalga Chlorella sp dikultivasi pada medium Walne, diaerasi melalui selang pada suhu ruang dan diberi perlakuan variasi cahaya (terang:gelap) 12:12 jam dan 18:6 jam selama 14 hari (Tabel 1). Pada awal kultivasi, mikroalga membutuhkan waktu 
untuk beradaptasi dengan kondisi sekitar. Hari pertama kultur mikroalga berwarna hijau muda. Hal ini dikarenakan jumlah sel masih sedikit yaitu sekitar 0,5 juta $\mathrm{sel} / \mathrm{mL}$ kultur. Jumlah sel tersebut sama untuk mikroalga yang diberi variasi cahaya (terang:gelap) 12:12 jam dan 18:6 jam. Pada hari ketujuh warna kultur semakin hijau. Hal tersebut menunjukkan bahwa mikroalga memperbanyak diri dengan meningkatnya jumlah sel. Pengamatan yang dilakukan pada hari keempat belas sebagai puncak pertumbuhan mikroalga diperoleh kultur berwarna hijau pekat dengan jumlah sel sebanyak 18,26 juta $\mathrm{sel} / \mathrm{mL}$ kultur pada (terang:gelap) 12:12 jam dan kultur berwarna hijau kekuningan dengan jumlah sel 20,34 juta sel/mL kultur pada (terang:gelap) 18:6 jam

Tabel 1. Kultur mikroalga Chlorella sp

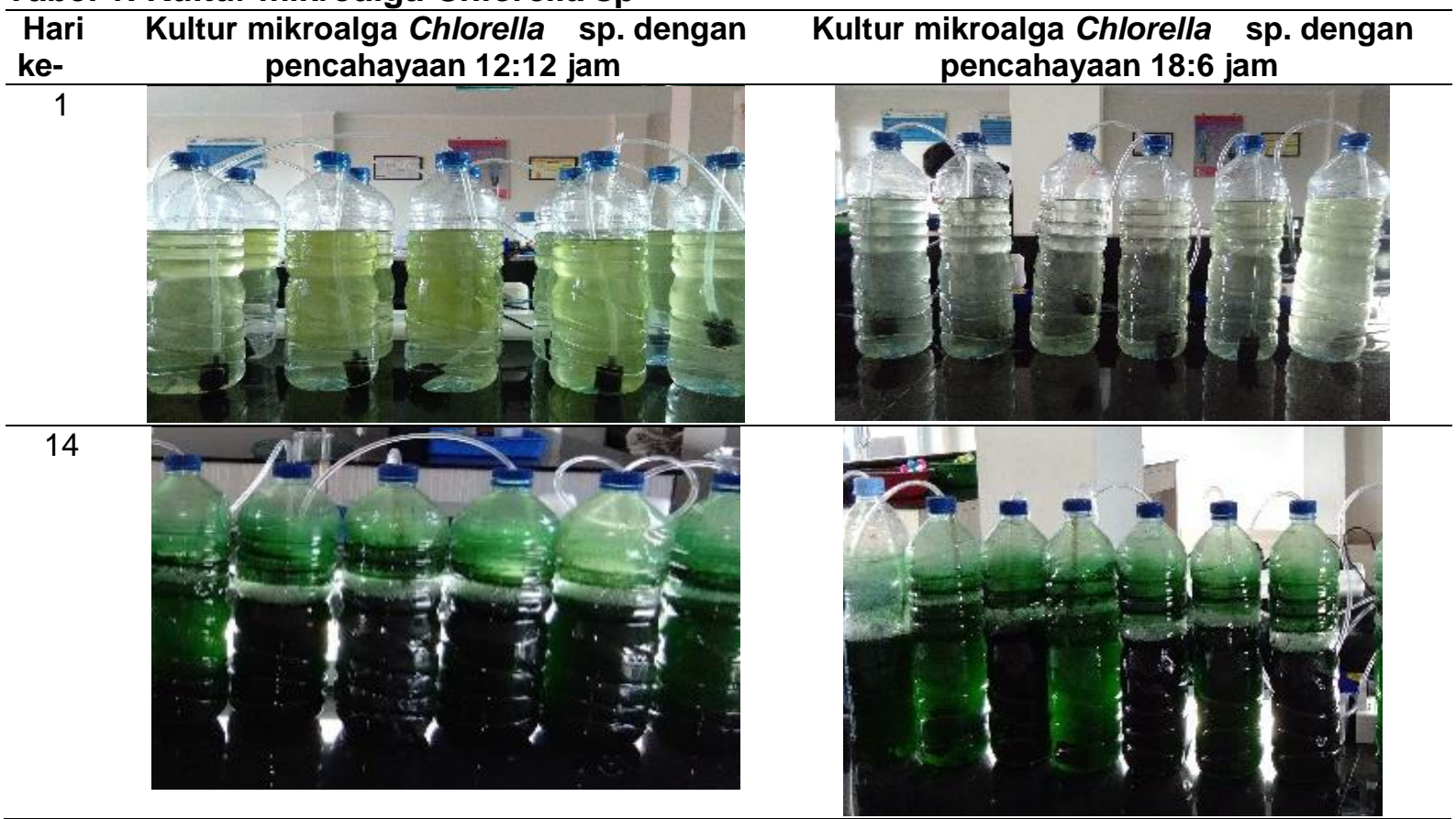

Mikroalga Chlorella sp. yang telah dikultivasi selama 14 hari dipanen dengan metode sentrifugasi. Metode sentrifugasi adalah metode yang paling sering digunakan untuk mengumpulkan biomassa mikroalga (Hadiyanto \& Azim, 2012). Metode sentrifugasi memisahkan berdasarkan berat jenis antara media pertumbuhan dan sel mikroalga. Selain itu metode sentrifugasi juga lebih singkat waktunya dibandingkan metode filtrasi. Biomassa hasil dari sentrifugasi adalah biomassa basah. Biomassa basah diperoleh sebanyak 40,04 g untuk variasi (terang:gelap) 12:12 jam dan 55,53 g untuk variasi (terang:gelap) 18:6 jam. Biomassa basah dihilangkan kadar airnya dengan oven pada suhu $35^{\circ} \mathrm{C}$ selama 72 jam. Pengeringan dengan suhu $35^{\circ} \mathrm{C}$ merupakan rentang suhu yang dapat menjaga kualitas kandungan kimia di dalam mikroalga (Silva et al., 2019). Rata-rata kadar air yang diperoleh pada biomassa mikraolga variasi (terang:gelap) 12:12 jam yaitu 91,46\% dan variasi (terang:gelap) 18:6 jam yaitu $89,03 \%$ (tabel 2).

\section{Ekstrak Chlorella sp.}

Biomassa kering mikroalga Chlorella $\mathrm{sp}$ diekstraksi dengan cara maserasi (perendaman) dalam etanol p.a sebanyak pada suhu kamar.Proses maserasi dilakukan selama 72 jam dan dilakukan penyaringan dengan untuk memperoleh maserat. Maserat yang diperoleh diuapkan hingga diperoleh ekstrak kental (ekstrak kasar) untuk variasi *terang:gelap) (tabel 3).

Kondisi lingkungan saat kultivasi tidak hanya berpengaruh terhadap pertumbuhan sel tetapi juga berpengaruh terhadap kestabilan dari senyawa antioksidan mikroalga (Karseno et al., 2013). Kondisi ca 
Tabel 2. Biomassa Chlorella sp. dengan variasi (terang:gelap) 12:12 jam dan 18:6 jam

\begin{tabular}{|c|c|c|}
\hline Hari ke- & $\begin{array}{c}\text { Biomassa kering } \\
\text { Chlorella sp. }\end{array}$ & $\begin{array}{c}\text { Massa } \\
\text { (q) }\end{array}$ \\
\hline $\begin{array}{l}\text { Variasi } \\
\text { (terang:gelap } \\
\text { ) } 12: 12 \text { jam }\end{array}$ & & 3,38 \\
\hline $\begin{array}{l}\text { Variasi } \\
\text { (terang:gelap } \\
\text { ) 18:6 jam }\end{array}$ & & 5,94 \\
\hline
\end{tabular}

cahaya mempengaruhi langsung pertumbuhan dan fotosintesis mikroalga (durasi dan intensitas). Kandungan senyawa fitokimia berperan untuk mencegah kerusakan oksidatif akibat radikal bebas, antibakteri, antijamur, dan antivirus.

Tabel 3. Ekstrak kasar Chlorella sp. dengan variasi (terang:gelap) 12:12 jam dan 18:6 jam

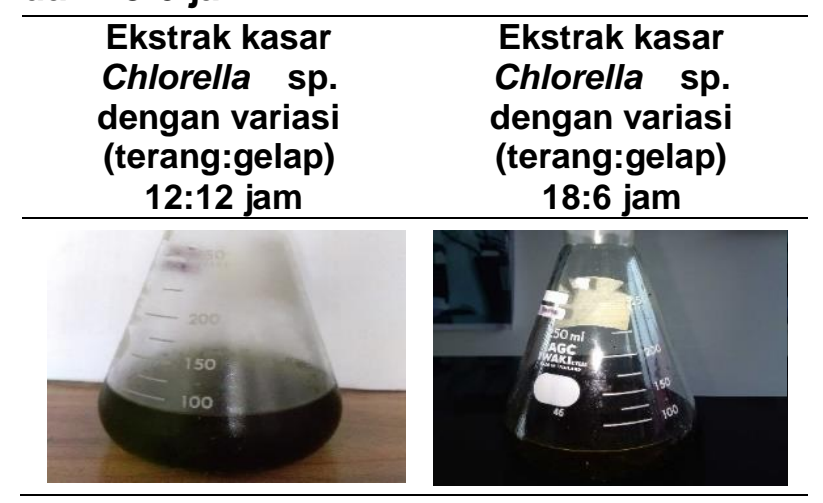

\section{Kandungan fitokimia ekstrak Chlorella sp.}

Senyawa alkaloid ditemukan pada kedua kelompok variasi cahaya dalam penelitian. Alkaloid bersifat sitotoksi, karena alkaloid dapat mengikat beta tubulin yang menghambat mitotic spinder fiber untuk pembelahan sel. Kandungan flavonoid juga ditemukan pada Chlorella sp yang diberi variasi (terang:gelap) 12:12 jam dan 18:6 jam (tabel 4). Flavonoid dapat dimanfaatkan untuk antimikroba, antivirus dan antikanker. Selanjutnya, saponin ditemukan pada kedua kelompok penelitian. Saponin secara umum bersifat sebagai antijamur dan antibakteri pada tanaman. Senyawa steroid hanya ditemukan pada Chlorella sp. variasi (terang:gelap) 12:12 jam. Steroid penting sebagai insektisida, antimikroba, antiparasit dan bersifat kardiotonik. Kuinon juga hanya ditemukan pada Chlorella sp. variasi (terang:gelap) 12:12 jam. Pada penelitian ini masih mencari literatur pendukung penyebab hilangnya kandungan steroid dan kuinon pada Chlorella dengan variasi (terang:gelap) 18:6 jam. Kuinon bermanfaat untuk antimikoba dan antitumor. Senyawa terpenoid ditemukan pada kedua kelompok mikroalga Chlorella sp. variasi (terang:gelap) 12:12 jam dan 18:6 jam. Terpenoid terdapat dalam kedua kelompok mikroalga. Terpenoid dapat dimanfaatkan untuk antiseptik dan ekspektoran (AbdelKarim et al., 2020).

Tabel 4. Kandungan fitokimia

\begin{tabular}{cc} 
Kandungan & Ekstrak kasar \\
fitokimia Chlorella & Chlorella sp. \\
sp. dengan variasi & dengan variasi \\
(terang:gelap) 12:12 & (terang:gelap) 18:6 \\
jam & jam \\
\hline
\end{tabular}

\begin{tabular}{llll|}
\hline & & & \\
\hline
\end{tabular}

Aktivitas antioksidan Ekstrak Chlorella sp.

Penentuan potensi antioksidan ekstrak Chlorella sp. dalam penelitian ini menggunakan metode DPPH (1,1-diphenyl2-picrylhydrazyl). Metode ini didasarkan pada perubahan warna karena adanya reaksi antara radikal bebas DPPH yang berwana ungu dengan satu atom hidrogen 
pada senyawa yang terkandung dalam sampel untuk membentuk senyawa 1,1diphenyl-2-picrylhydrazin berwarna kuning (Molyneux, 2004). Metode DPPH merupakan metode in vitro yang sering dipilih sebagai metode pengujian aktivitas antioksidan karena sederhana, mudah, cepat, peka dan memerlukan sedikit sampel (Lung \& Destiani, 2018). Pengukuran absorbansi ekstrak Chlorella sp. menggunakan spektrofotometer UV-Vis pada panjang gelombang $516 \mathrm{~nm}$. Konsentrasi ekstrak mikroalga dan vitamin $C$ yang digunakan dalam penelitian ini adalah 5 ppm, 10 ppm, 25 ppm, 50 ppm dan 100 ppm. Vitamin C merupakan larutan pembanding yang paling sering dalam penentuan aktivitas antioksidan karena vitamin C . Vitamin C digunakan sebagai

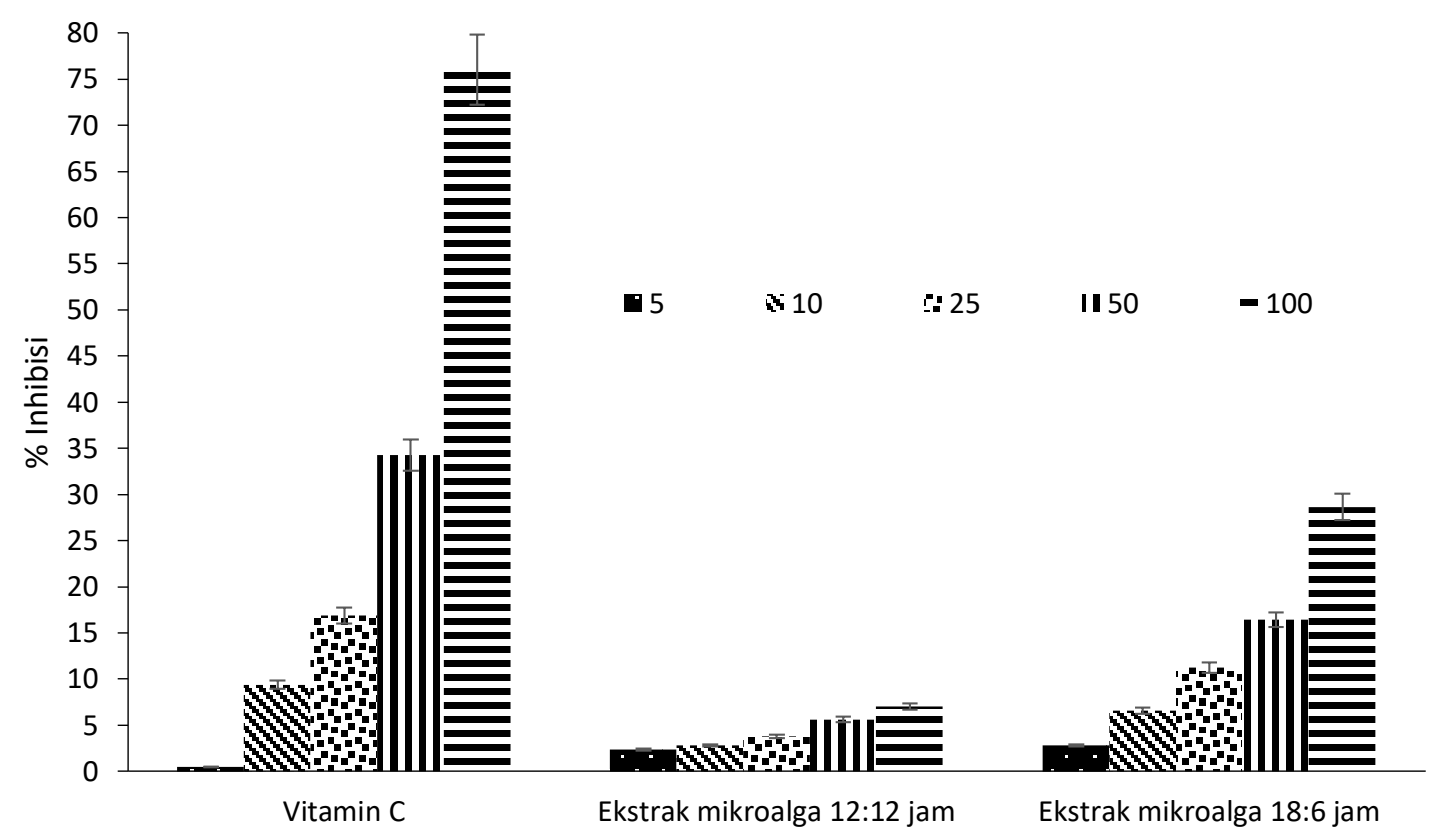

Gambar 1. Persen inhibisi vitamin C dan ekstrak mikroalga

Data persen inhibisi digunakan untuk penentuan nilai konsentrasi dalam peredaman radikal DPPH 50\% (IC50). Nilai IC50 yang semakin kecil menunjukkan bahwa aktivitas antioksidannya semakin kuat (Molyneux, 2004). Pada Gambar 2 disajikan regresi linear Vitamin C, ekstrak Chlorella sp. variasi waktu pencahayaan (terang:gelap) 12:12 dan 18:6. Persamaan linear yang diperoleh untuk Vitamin C dengan beberapa konsentrasi diperoleh 17,606x-25,399 dan nilai koefisien larutan pembanding karena vitamin C memiliki kemampuan antioksidan yang sangat kuat dibanding vitamin $A$ dan $E$ (Lung \& Destiani, 2018).

Hasil penelitian yang disajikan pada Gambar 1 menunjukkan bahwa semakin tinggi konsentrasi maka semakin tinggi persen inhibisi. Hal tersebut bermakna bahwa semakin tinggi konsentrasi, maka semakin tinggi kandungan antioksidannya sehingga semakin besar kemampuan dalam menghambat radikal bebas. Kemampuan inhibisi yang paling besar dimiliki oleh Vitamin C, kemudian kemampuan inhibisi ekstrak Chlorella sp. dengan variasi waktu pencahayaan (terang:gelap) 18:6 lebih besar dibandingkan ekstrak Chlorella sp. (terang:gelap) 12:12 jam. 


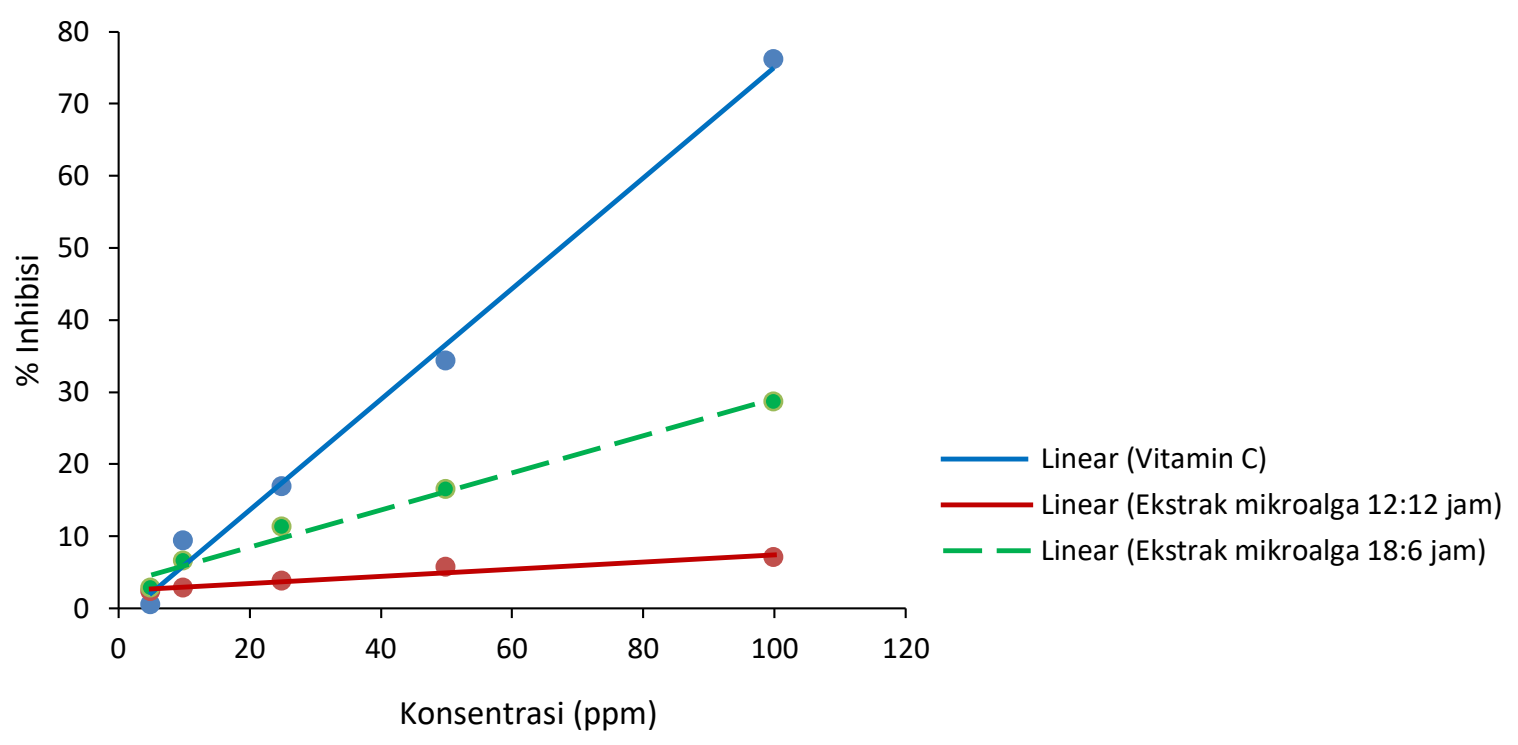

Gambar 2. Regresi linear sederhana dari persen inhibisi

ekstrak Chlorella sp. pada dua variasi waktu cahaya ditentukan dengan nilai $I_{50}$. Vitamin $\mathrm{C}$ memberikan hasil $\mathrm{IC}_{50}$ sebesar 4,283 dengan kriteria sangat kuat. Ekstrak mikroalga Chlorella sp. Chlorella sp variasi waktu pencahayaan (terang:gelap) 12:12 jam memiliki $I_{50}$ sebesar 40,421 dan 18:6 jam memiliki $I_{50}$ sebesar 8,992. Ekstrak Chlorella sp. Chlorella sp variasi waktu pencahayaan (terang:gelap) 18:6 jam memiliki kemampuan antioksidan lebih kuat dibandingkan ekstrak Chlorella sp. 12:12 jam (tabel 5). Menurut Coulombier et al.,
(2020) bahwa intensitas cahaya memiliki pengaruh kuat pada kapasitas antioksidan mikroalga. Aktivitas antioksidan lebih baik pada intensitas cahaya tinggi dibandingkan pada intensitas cahaya rendah. Mikroalga pada intensitas cahaya tinggi menghasilkan biopigmen karotenoid sebagai respon terhadap kondisi lingkungan(Sugiati et al., 2019). Selain itu, kondisi nutrisi media dan suhu juga memicu pembentukan biopigmen karotenoid sehingga meningkatkan aktivitas antioksidan (Ivanova et al., 2016).

Tabel 5. Nilai IC50 Ekstrak Chlorella sp. dengan variasi waktu pencahayaan

\begin{tabular}{lcccc}
\hline & $\mathbf{Y}=\mathbf{a + b x}$ & $\mathbf{R 2}$ & $\mathbf{I C}_{50}$ & Kriteria $\mathbf{I C}_{50}$ \\
\hline Vitamin C & $17,606 \mathrm{x}-25,399$ & 0,8671 & 4,283 & Sangat kuat \\
Ekstrak mikroalga 12:12 & $1,2207 x+0,6573$ & 0,9548 & 40,421 & Sangat kuat \\
jam & & & & \\
Esktrak mikroalga 18:6 & $6,1502 x-5,3052$ & 0,9357 & 8,992 & Sangat kuat \\
jam & &
\end{tabular}

\section{KESIMPULAN}

Berdasarkan penelitian ini diperoleh kesimpulan bahwa terdapat perbedaan kandungan fitokimia pada mikroalga Chlorella sp. yang diberi variasi waktu pencahayaan (terang:gelap) 12:12 jam dan 18:6 jam. Pada mikroalga 12:12 jam memiliki 6 kandungan fitokimia yang diuji yaitu alkaloid, flavonoid, saponin, steroid, kuinon dan terpenoid. Sedangkan pada mikroalga 18:6 jam memiliki 4 kandungan fitokimia yang diuji yaitu alkaloid, flavonoid, saponin dan terpenoid. Aktivitas antioksidan dari ekstrak mikroalga Chlorella sp. yang diberi variasi waktu pencahayaan (terang:gelap) 18:6 jam lebih kuat dibanding ekstrak mikroalga Chlorella sp. yang diberi variasi waktu pencahayaan (terang:gelap) 12:12 jam.

\section{UCAPAN TERIMA KASIH}

Peneliti mengucapkan terimakasih kepada Kementerian Pendidikan, Kebudayaan, Riset dan Teknologi yang telah mendanai penelitian ini berdasarkan Surat Keputusan Nomor SK:9/E1/KPT/2021 
dan Perjanjian Kontrak Nomor 135/LL10/PG-PDTT/2021.

\section{REFERENSI}

Abdel-Karim, O. H., Gheda, S. F., Ismail, G. A., \& Abo-Shady, A. M. (2020). Phytochemical Screening and antioxidant activity of Chlorella vulgaris. Delta Journal of Science, 41(1), 81-91. https://doi.org/10.21608/djs.2020.1392 31

Acurio, L. P., Salazar, D. M., Valencia, A. F., Robalino, D. R., Barona, A. C. Alvarez, F. C., \& Rodriguez, C. A. (2018). Antimicrobial potential of Chlorella algae isolated from stacked waters of the Andean Region of Ecuador. IOP Conference Series: Earth and Environmental Science, 151(1). https://doi.org/10.1088/1755-

1315/151/1/012040

Coulombier, N., Nicolau, E., Le Déan, L., Antheaume, C., Jauffrais, T., \& Lebouvier, N. (2020). Impact of light intensity on antioxidant activity of tropical microalgae. Marine Drugs, 18(2).

https://doi.org/10.3390/md18020122

Demirbas, A., \& Demirbas, F. M. (2010). Improved bolted joint reliability: Innovative gasket, unsurpassed recovery. In Fuels and Petrochemicals Division 2014 - Core Programming Area at the 2014 AIChE Spring Meeting and 10th Global Congress on Process Safety (Vol. 1). Springer. https://doi.org/10.1007/978-1-84996050-2

Hadiyanto, \& Azim, M. (2012). Penerbit \& Percetakan UPT UNDIP Press SEMARANG. 1-138.

Harborne, A. . (1998). Harborne, J.B. (1998) Textbook of Phytochemical Methods. A Guide to Modern Techniques of Plant Analysis.

Ivanova, N., Gugleva, V., Dobreva, M., Pehlivanov, I., Stefanov, S., \& Andonova, V. (2016). We are IntechOpen, the world' $s$ leading publisher of Open Access books Built by scientists, for scientists TOP $1 \%$. Intech, i(tourism), 13.

Karseno, Handayani, I., \& Setyawati, R. (2013). Aktivitas Dan Stabilitas Antioksidan Ekstrak Pigmen Alga.
Agritech, 33(4), 371-376.

Lung, J. P. ., \& Destiani, D. . (2018). Uji Aktivitas Antioksidan Vitamin A, C, E dengan Metode DPPH. Farmaka, 15(1), 53-62.

Metsoviti, M. N., Papapolymerou, G., Karapanagiotidis, I. T., \& Katsoulas, N. (2020). Effect of light intensity and quality on growth rate and composition of Chlorella vulgaris. Plants, 9(1), 1-17. https://doi.org/10.3390/plants9010031

Molyneux, P. (2004). The Use of the Stable Free Radical Diphenylpicryl-hydrazyl (DPPH) for Estimating Antioxidant Activity. Songklanakarin Journal of Science and Technology, 26(December 2003), 211-219. https://doi.org/10.1287/isre.6.2.144

Novianti, T., Zainuri, M., \& Widowati, I. (2019). Aktivitas Antioksidan dan Identifikasi Golongan Senyawa Aktif Ekstrak Kasar Mikroalga Chlorella Vulgaris Yang Dikultivasi Berdasarkan Sumber Cahaya Yang Berbeda. Barakuda 45: Jurnal IImu Perikanan Dan Kelautan, 1(2), 72-87. https://doi.org/10.47685/barakuda45.v1 i2.44

Nurachman, Z., H, H., Rahmaniyah, W. R., Kurnia, D., Hidayat, R., Prijamboedi, B., Suendo, V., Ratnaningsih, E., Panggabean, L. M. G., \& Nurbaiti, S. (2015). Tropical marine Chlorella sp. PP1 as a source of photosynthetic pigments for dye-sensitized solar cells. In Algal Research (Vol. 10). https://doi.org/10.1016/j.algal.2015.04. 009

Silva, A. F. R., Abreu, H., Silva, A. M. S., \& Cardoso, S. M. (2019). Effect of ovendrying on the recovery of valuable compounds from Ulva rigida, Gracilaria sp. and fucus vesiculosus. Marine Drugs, 17(2). https://doi.org/10.3390/md17020090

Sugiati, N., Masithah, E. D., Tjahjaningsih, W., \& Abdillah, A. A. (2019). The Increase in $\beta$-carotene Content in Dunaliella salina from the Application of Different Light Intensities. IOP Conference Series: Earth and Environmental Science, 236(1). https://doi.org/10.1088/17551315/236/1/012001 